\title{
Pharmacotherapy for Pediatric Neurogenic Bladder
}

\author{
Pawel Kroll (i)
}

Published online: 15 July 2017

(c) The Author(s) 2017. This article is an open access publication

\begin{abstract}
Neurogenic bladder (NB) is a nonspecific term that may describe conditions ranging from areflectic noncontractile bladder to detrusor overactivity. The most common cause of NB in children is the presence of dysraphic malformations. Urodynamic evaluations make it possible to describe bladder dysfunctions and to plan a therapeutic strategy for each patient. In a child with NB there are two major dangerous functional problems seen in urodynamic investigations: high intravesical pressure in the storage phase and high pressure during urination. The basic goals of urologic treatment for a child with NB are the protection of the urinary tract from complications and improvement of continence. Treatment for a child with NB is usually conservative, and focuses on achieving safe bladder pressures during storage with reliable emptying, via voiding or catheterization. The two most important forms of conservative treatment are clean intermittent catheterization and pharmacological treatment of functional disorders. Some drugs are used in the treatment of functional disorders in children with $\mathrm{NB}$, but none of the drugs are officially approved for small children and babies.
\end{abstract}

Paweł Kroll

pawelkroll.poczta@gmail.com

1 Neuro-urology Unit, Pediatric Surgery and Urology Clinic, Ul. Pamiątkowa 2/42, 61-512 Poznań, Poland

2 Poznan University of Medical Sciences, Poznań, Poland

\section{Key Points}

Pharmacotherapy is one of the most important elements in the treatment of a pediatric patient with neurogenic bladder. Some groups of drugs have been described to improve the function of the lower urinary tract.

Oxybutynin was the first drug formally approved, but only for children $>5$ years of age. It was followed by tolterodine and recently by solifenacin. There is not enough evidence-based medicine to prescribe all of the anticholinergics or $\alpha$-blockers in children.

\section{Introduction}

The normal function of the urinary bladder is to store and expel urine in a coordinated, controlled fashion. This coordinated activity is regulated by the central and peripheral nervous systems. Neurogenic bladder (NB) is a term applied to a malfunctioning urinary bladder due to neurologic dysfunction or insult emanating from internal or external trauma, disease, or injury [1].

The organs of the urinary system are traditionally classified as belonging to the upper or the lower urinary tract. The lower urinary tract (LUT) anatomically comprises the bladder and sphincters, which together form one operating unit. Due to the specificity of the performed action, part of the bladder dome is known as the detrusor, and the sphincters are classified as internal and external. However, for practical reasons, we normally simplify the issue and 
talk about functional disorders of the LUT (i.e. detrusor/ sphincter dysfunctions), also referred to in short as bladder dysfunctions.

Micturition, or urination, occurs involuntarily in infants and young children until the age of 3-5 years, and at this time of life is controlled only by the autonomic part of the nervous system, after which it is regulated voluntarily [2]. In older children, the correct functioning of the bladder/ sphincter unit is manifested by periodic, conscious controlled urination in portions adequate to the patient's age with continence maintained between particular acts of micturition.

The evaluation of the bladder function in older children should begin with keeping, for at least three consecutive days, a voiding diary (VD), also known as a frequency/ volume chart. It contains data on the hours and volumes of voided or catheterized urine. On the basis of the diary we are able to establish the three most important parameters: the number of micturitions per $24 \mathrm{~h}$, the maximum voided volume testifying to the anatomical capacity of the bladder, and the functional bladder capacity — an average voided or catheterized volume. The VD also provides a reliable noninvasive estimate of bladder capacity in children with NB. However, the potential for poor agreement with urodynamic measurements means the two techniques should be seen as supplementary, rather than interchangeable, in this group [3].

The literature offers various formulas for the calculation of age-related bladder capacity for children. The most frequently used is Hjälmås' formula, expected bladder capacity $\quad(\mathrm{EBC})$ : volume $\quad(\mathrm{mL})=30 \times$ age $\quad$ (in years $)+1]$. Bladder capacity increased with age and body weight from $30 \mathrm{~mL}$ in neonates to $350 \mathrm{~mL}$ in 12 -year-old children [4-6].

\section{The Practical Division of Urination Problems}

Analyzing the data obtained from VD, we can identify three groups of patients:

1. Those with normal/correct bladder function. The correct condition is regular urination, fully controlled by the patient, in portions adequate to age, without complaints.

2. Those voiding, but abnormally. The child passes urine periodically but the volumes are not correct:

(A) Increased voiding frequency. Frequent passing of urine in decreased volumes: $<65 \% \mathrm{EBC}$, and $>8$ voids per day, ("Overactive Bladder Syndrome" [OAB] with frequency and urgency symptoms).

(B) Decreased voiding frequency. Sporadic passing of large portions of urine: $>150 \% \mathrm{EBC},<3$ voids per day, ('Lazy Bladder Syndrome', voiding postponements).

(C) Irregular voiding characterized by considerable differences in the voided volume of urine, which is commonly accompanied by a significant amount of residual urine after urination $(>10-20 \%$ of EBC).

Each of the above-described conditions may be accompanied by additional LUT symptoms, such as urgency, hesitancy, straining, or intermittency. In each group, urine incontinence or infections of the urinary tract may occur.

3. Those who have lost control over their bladder and do not urinate at all.

(A) Total lack of control over urination. In children with dysraphic malformations, the fibers of the efferent and afferent, motor and sensory pathways, and spinal centers responsible for controlling bladder and sphincter functions are seriously damaged. In children who have no sensation of bladder fullness and lack the urethra sensation, or in whom that sensation is considerably decreased, we observe the inability to urinate voluntarily, in a controlled manner. The result in the majority of them is uncontrolled urine leaking characteristic of severe cases of NB [7].

\section{Causes of Neurogenic Lower Urinary Tract Dysfunctions}

NB is a nonspecific term that may describe conditions ranging from areflectic noncontractile bladder to detrusor overactivity (DO) [1, 8].

The neural circuitry that controls the process of urine storage and voiding is complex and highly distributed, it involves pathways at many levels of the central nervous system including the brain and the spinal cord, and also the peripheral nervous system, and it is mediated by multiple neurotransmitters. Congenital malformations, acquired diseases, or injuries of the nervous system can cause the reemergence of involuntary or reflex micturition, leading to problems with urination, loss of ability to urinate, and urinary incontinence [2, 9].

The distinction still holds between neurogenic LUT dysfunction or simply NB dysfunctions and non-neurogenic, idiopathic bladder dysfunctions. Various diseases and events affecting the nervous systems controlling the bladder and sphincters may cause neurogenic LUT dysfunction. The resulting NB depends grossly on the location and the extent of the neurologic lesion $[1,10]$. In patients 
with $\mathrm{NB}$, dysfunctions of the detrusor and the sphincter complex are caused by either a known congenital defect of the nervous system or by acquired, post-traumatic, and post-inflammatory or neoplastic damage to the nervous system. The most common cause of NB in children is the presence of dysraphic malformations, or spinal dysraphism (SD). Other causes of neurogenic dysfunction involving the spine include sacral agenesis, tethered spinal cord, or malformations associated with an imperforate anus, cloacal malformations, spinal cord injuries, central nervous system abnormalities including cerebral palsy, and learning disabilities such as attention deficit hyperactivity disorder (ADHD) or attention deficit disorder [9, 11, 12].

In patients with idiopathic bladder dysfunctions (IB), neurological examinations fail to reveal any pathology in the nervous system. Diagnosis of IB is not so obvious, as some studies demonstrated various pathologies in the nervous system, such as parasympathetic hyperactivity in children diagnosed with idiopathic OAB syndrome, suggesting a neurogenic dysfunction in their autonomic nervous system [13-15].

Dysraphic malformations (SD) are characterized by a considerable variety of clinical manifestations, from occult spinal dysraphism, non-symphysis of single lumbal vertebral arches, to extensive open myelomeningocele (MMC) reaching the thoracic region with co-existing hydrocephalus [11]. The prevalence of SD was reported to be 2-6.1 per 10,000 live births $[9,12,16,17]$. The type of urinary tract dysfunction detected is not clearly linked to the defect morphology (open, closed), the level of dysraphism, or the extensiveness of the cleft. Children with socalled occult spinal dysraphism form a specific group of patients in which the progressive damage of the nervous system may initially manifest itself solely in bladder dysfunction with gradually increasing incontinence. In children with occult spinal dysraphism, socially acceptable continence is achieved only in $78 \%$ of the children [18]. About $95 \%$ of children with open MMC do not urinate at all; in a study by Reiner et al. of 108 consecutive patients with MMC aged 5-12 years, only seven (6.5\%) achieved spontaneous urinary continence; of these, five $(5.4 \%)$ with normal micturition and two with urgency [19]. According to Jørgensen et al., even with the help of pharmacotherapy and surgical procedures, fecal and urinary continence could be achieved in only $81 \%$ and $62 \%$ patients with open SD, respectively [20]. Even in utero operations did not improve the function of LUT in children with MMC; while in utero closure of MMC has been shown to decrease rates of ventriculoperitoneal shunting and improve motor function, it is not associated with any significant improvement in LUT function compared with repair after birth. Therefore, it is recommended that patients who undergo spinal cord defect closure during gestation be evaluated and treated in the same manner as those with MMC but without fetal intervention [12, 21-24].

\section{Initial Management of a Child with Neurogenic Bladder}

An infant with suspected NB after spinal cord surgery should first undergo physical examination, with particular attention paid to the condition of the genitourinary system. Physical appearance, sensation, and neurological reflexes in the perineal region should be evaluated. Special attention should be paid to the manner of urinating; spontaneous urine discharge from the urethra in droplets is often detected in children with SD, and urine leakage after pressing above the pubic symphysis is observed.

When introducing a catheter into the bladder, the examining clinician should observe the child's reactions in order to evaluate the urethra sensation. The tonus of anal sphincters should be checked, which is predominantly found to be lacking.

Further tests are performed in a certain sequence, beginning with urinalysis and urine culture followed by biochemical tests, the analysis of the morphology of the urinary tract (ultrasonography, cystography, renal scans, intravenous pielography, and computer tomography) and then the evaluation of the bladder and sphincter functions in urodynamic testing. Urodynamic evaluations make it possible to describe bladder dysfunctions and dysfunctions of the urethral sphincters, while the other tests are used to evaluate the type and severity of complications caused by the neurogenic urinary system dysfunctions.

With data from the VD, urodynamic tests can be performed in a reliable manner. In toilet-trained children, neuro-urologic evaluation should begin with the simplest urodynamic test-uroflowmetry. In order to obtain the complete picture of urination effectiveness, ultrasonographic evaluation of the amount of residual urine in the bladder after urination is always necessary. More complicated urodynamic tests such as cystometry, voiding cystometry, and video-urodynamics are recommended for patients with multi-symptomatic forms of NB $[1,7,10,11]$.

The first urodynamic tests in children after MMC surgery with suspected NB should be performed in early infancy; the subsequent tests ought to be the controls, because newborns with MMC and initially normal urodynamic studies are at risk for neurologic deterioration secondary to spinal cord tethering, especially during the first 6 years of life. Close follow-up of these children is important for early diagnosis and prevention of progressive urinary tract deterioration [25]. 
Conventionally, the etiology of NB is divided into the following categories: central, peripheral, or mixed. But this classification has a very small role to play in therapeutic decision making. Management is dictated by the basic state of the bladder function evaluated in urodynamic investigation [26].

Analyzing data from urodynamic investigations, Madersbacher described four groups of patients with NB:

- Detrusor overactivity with sphincter overactivity

- Detrusor inactivity with sphincter overactivity

- Detrusor overactivity with sphincter inactivity

- Detrusor inactivity with sphincter inactivity.

Of all four types, only the combination of sphincter inactivity and detrusor inactivity is inherently 'safe' in that, untreated, it will not lead to urinary tract damage, although it does result in incontinence and increased rates of urinary tract infection. The European Association of Urology recommends Madersbacher's modified functional classification for motor function of LUT based on urodynamic and clinical findings. Based on this simple, but clinically useful, classification of detrusor-sphincter dysfunction, the therapeutic strategy is provided for each patient $[10,27]$.

\section{Risk Factors}

Many parameters are evaluated in the urodynamic test; however, the following are the most important for predicting risk of complications:

1. The detrusor leak point pressure (DLPP)—the lowest value of detrusor pressure at which leakage is observed in the absence of abdominal strain or detrusor contraction. An increased risk of development of complications occurs in patients with DLPP $>40 \mathrm{~cm}$ $\mathrm{H}_{2} \mathrm{O}$.

2. Bladder compliance or detrusor compliance. Relationship between change in bladder volume $(\Delta V)$ and change in detrusor pressure ( $\triangle P$ det): $C=\Delta V / \Delta P$ det $\left(\mathrm{mL} / \mathrm{cm} \mathrm{H}_{2} \mathrm{O}\right)$. Patients with a bladder compliance of $<20 \mathrm{~mL} / \mathrm{cm} \mathrm{H}_{2} \mathrm{O}$ are 4.3 times more likely to have bladder diverticuli or vesicoureteral reflux (VUR) compared with patients with compliance $>20 \mathrm{~mL} / \mathrm{cm}$ $\mathrm{H}_{2} \mathrm{O}$.

3. Detrusor sphincter dyssynergia (DSD) is a detrusor contraction concurrent with an involuntary contraction of the urethra and/or periurethral striated musculature. Up to $72 \%$ of children with DSD will develop complications without proper treatment.

4. Elevated storage pressure with decreased bladder capacity. Both are caused by detrusor overactivity (DO). DO is expressed by involuntary detrusor contractions during filling, spontaneous or provoked. The diagnosis of DO is made based on the urodynamic investigations. If those contractions are caused by a neurogenic condition we call them neurogenic detrusor overactivity (NDO). According to current knowledge, elevated storage pressure in the bladder, either alone or combined with VUR, is the most important risk factor for renal damage $[6,10,28-33]$.

According to Madersbacher's classification, the most dangerous findings for a child with NB is a combination of DO with sphincter overactivity. In this type of NB there are two major dangerous functional problems:

- high intravesical pressure in the storage phase, and/or

- high pressure during leakage of urine or during urination.

From a practical point of view for the patient, DO leads to a decrease in functional bladder capacity and to urinary incontinence. On the other hand, sphincter overactivity leads to ineffective voiding or makes voiding impossible. High pressure in the storage phase is caused mainly by DO and/or by decreased bladder wall compliance.

$\mathrm{OAB}$ is a syndrome consisting of urinary urgency/frequency, with or without urinary incontinence, in the absence of a causative infection or pathological conditions [6].

Patients, with symptoms of OAB, where the cause is neurogenic, are often referred to as having neurogenic $\mathrm{OAB}$ (nOAB). The symptoms of OAB usually stem from $\mathrm{DO}$. Where the cause of $\mathrm{DO}$ is neurogenic, the condition is known as neurogenic DO (nDO). $\mathrm{nDO}$ is most commonly seen in patients with SD and spinal cord injury, but also multiple sclerosis or Parkinson's disease. In the majority of cases in the literature, urinary incontinence among patients with underlying neurological conditions was found to be associated with $\mathrm{nOAB}$ and attributable to $\mathrm{DO}[8,34,35]$. The prevalence of urologic symptoms ranged from $12 \%$ in an Italian study of children with occult spinal dysraphism to $94.9 \%$ children with SD in Taiwan $[18,36]$.

Decreased compliance is often associated with irreversible changes in detrusor muscle ultrastructure, and is often caused by increased activity of the cholinergic part of the autonomic nervous system. Some authors observed an improvement in bladder compliance after anticholinergic therapy, others observed no improvement. There are also papers describing histopathologic changes, such as an increase in connective tissue with subsequent decrease in muscle tissue in fibrotic bladder wall specimens in children with decreased bladder compliance. Also, observations of lack of improvement after Botox injections in children with decreased bladder compliance suggest that in some cases decreased compliance could be resistant to any pharmacotherapy [33, 37-41]. 
A decrease in intravesical pressure could be achieved mainly by abolishing DO. Some drugs are used in pharmacotherapy for DO.

\section{Proactive versus Expectant Management}

The philosophy of expectant management comes from the assumption that $<10 \%$ of children with congenital NB will develop satisfactory bladder control without the need for clean intermittent catheterization (CIC); all parents are initially counseled and reminded at periodic follow-up to expect this intervention by the age of toilet training if urodynamic evaluation does not indicate earlier management [42].

Proactive management, which is more popular among urologists, is based on data from urodynamic evaluations performed in a newborn and early institution of CIC and anticholinergics.

The most frequently used proactive approach is defined by early and regular urodynamic testing. Ideally, CIC with or without pharmacotherapy is started early based on urodynamic findings, before the development of upper tract changes. Proactive bladder treatment with the prophylactic institution of intermittent catheterization and pharmacologic, anticholinergic therapy in the newborn significantly reduced the incidence of complication development, upper urinary tract deterioration, and need for surgical intervention $[7,9,30,43-45]$.

\section{Goals of Treatment}

The treatment of patients with NB is a multi-directional and complicated process. There are three basic goals of urologic treatment of a child with NB:

- optimization of bladder emptying,

- protection of the urinary tract from complications,

- improvement of continence.

Treatment for a child with NB begins with the conservative methods. The two most important forms of conservative treatment for a child with $\mathrm{NB}$ are CIC and pharmacologic treatment of functional disorders found in urodynamic studies.

\section{Intermittent Catheterization}

Jack Lapides introduced CIC in the 1970s. This method is a simple and effective way of achieving all the goals of treatment mentioned above [46]. CIC done at regular intervals from the newborn period has several advantages: it empties the bladder adequately without leaving any residual urine and hence there is no risk of infection, it keeps the upper tracts safe from reflux prior to high pressure voiding, and later is a valuable tool to keep the child dry [31-33, 44]. What is important is the early institution of CIC, as it seems to improve the compliance of caregivers and their ability to assist the child in coping with his/ her condition [47].

\section{Pharmacotherapy}

The second tool in the conservative treatment for a child with NB is pharmacotherapy. Pharmacologic therapy is defined as any therapy based on drugs [6].

\subsection{Antimuscarinic Drugs}

Antimuscarinic or anticholinergic drugs represent the mainstay of pharmacologic treatment for both idiopathic and neurogenic DO. Involuntary contractions of the detrusor muscle during the filling phase are mediated by acetylcholine-induced stimulation of bladder muscarinic receptors. Since oxybutynin was introduced in the early 1970s, antimuscarinic medications have been extensively studied in patients with $\mathrm{nDO}$, with encouraging results. Relative to placebo, anticholinergic drugs are associated with a $40 \%$ increased likelihood of cure or improvement, and a significantly decreased number of leakage and voiding episodes [48, 49].

Most antimuscarinics are tertiary amines and are metabolized by the P450 enzyme system to active or inactive metabolites. Only trospium chloride is a quaternary amine. The most commonly involved P450 enzymes are CYP2D and CYP3A4 [50]. These drugs act against the muscarinic receptors on the wall of the detrusor muscle, relax it, and thereby decrease intravesical pressures and overactive contractions and indirectly increase functional bladder capacity. Acetylcholine is generated and released from the cholinergic nerves, but also from the urothelium, binding to M2 and M3 receptors. Those receptors have been shown to evoke smooth muscle contraction. Antimuscarinics have anti-spasmodic but also local anesthetic and calcium channel blocking properties that augment their effect on the DO [49, 51-54].

M1 receptors are found in the brain, salivary glands, and sympathetic ganglia, which account for most of the side effects noted with antimuscarinic drugs. Dry mouth and constipation are the most common symptoms. Gastroesophageal reflux, blurry vision, urinary retention, and cognitive side effects can also occur; these symptoms are generally less frequent and bothersome in children than in adult patients [55-57]. 
Compliance and persistence with antimuscarinic therapy remain poor are this is generally considered to be due to lack of efficacy or because of the troublesome side effects [58]. A study based on prescription data from the UK estimated that discontinuation rates at 12 months for patients on antimuscarinics ranged between 65 and $86 \%$ [59]. That was an adult study, but in 2009 a disproportionately high number of central nervous system adverse event cases were reported in pediatric patients compared with adult patients, so some studies were undertaken on this issue [60].

Giramonti, in a double-blinded crossover trial, found that oxybutynin and tolterodine do not have a deleterious effect on children's attention and memory [61]. More recently, no significant differences in behavior were found between children with NB with and without long-term use of antimuscarinics [62].

Seven different antimuscarinics are currently marketed for the treatment of DO: oxybutynin, tolterodine, propiverine, trospium, solifenacin, darifenacin, and fesoterodine. Not all of those drugs are equally available on the market in different countries. It is the same with the formulation, oxybutynin syrup, patches, gels or extendedrelease (ER) tablets of oxybutynin and tolterodine are available, but not in every country. The most popular antimuscarinic drug is oxybutynin in a 5-mg immediaterelease (IR) tablet formulation [63].

According to Madhuvrata et al., in many studies of children and grown-up patients, none of the antimuscarinic drugs have been shown to be superior to one another [64]. The review by Buser et al., including randomized controlled trials of different formulations and dosages of antimuscarinics, concluded that there was no clinically relevant difference in efficacy between antimuscarinics, but in terms of safety, high dosages of oxybutynin and propiverine were associated with a greater risk of adverse events [65]. Novara et al. reported that ER formulations offered advantages in terms of efficacy and safety compared with IR formulations [66]. In adult trials, quantitative electroencephalographic data suggest that oxybutynin has more CNS effects than trospium or tolterodine [67]. None of the antimuscarinic drugs are authorized for use in infants and small children. Oxybutynin became the first one approved by the US Food and Drug Administration (FDA), followed by tolterodine, but only for children above 5 years of age [68]. In a study by Blais et al., the most prescribed antimuscarinic drug as a first-line therapy of DO in children in Canada was oxybutynin followed by tolterodine, trospium, solifenacin, and darifenacin [55]. In the US, the most common prescriptions for NB in children were for oxybutynin (78\%) and tolterodine (17\%) [63].

\subsubsection{Oxybutynin}

Oxybutynin hydrochloride is a tertiary amine that is well absorbed and undergoes hepatic metabolism by the cytochrome P450 system into metabolites, with N-desethyloxybutynin as the primary one. It has a high affinity for muscarinic receptors, higher for M3 and M1 than for M2 subtypes [69, 70]. Oxybutynin was the first formally approved antimuscarinic drug for use in children $[33,71,72]$.

Oxybutynin is safe and efficacious in treating pediatric NB. Oxybutynin is available in several formulations: syrup, IR and ER tablets, and also transdermal patches and a solution for intravesical instillation. The drug is tolerable and the safety profile suggests that adjustment of dosage for age may not be strictly observed. It is administered orally in a dosage of $0.2 / 0.4 / 0.6 \mathrm{mg} / \mathrm{kg} /$ day in two to four divided doses. The dose has to be limited sometimes in view of the side effects [73, 74].

In 2014, Momper et al. analyzed data from trials submitted to the US FDA showing that only oxybutynin demonstrated efficacy in children with NB. The lack of demonstrable efficacy for the remainder of the antimuscarinics illustrates that future trials should give careful attention to testing a range of doses, using objectively measured, clinically meaningful endpoints, and selecting clinical trial designs that are both interpretable and feasible [75].The current experience with drugs other than oxybutynin is still limited in children with NB.

\subsubsection{Tolterodine}

Tolterodine is available for children as a solution, or as IR or ER tablets. In a study by Reddy et al. in children with NB, drug formulation and dosing were based on age ( 4 months -4 years, tolterodine oral solution $0.2-2 \mathrm{mg}$ twice daily; 5-10 years, oral solution 0.5-4 mg twice daily; 11-16 years, ER capsules 2,4 , or $6 \mathrm{mg}$ once daily). Both tolterodine formulations were effective and well tolerated [76].

Three open-label, dose-escalating studies were conducted in children with NB and DO. In studies 1 (patients aged 1 month to 4 years) and 2 (5-10 years), patients received tolterodine solution $0.03,0.06$, and $0.12 \mathrm{mg} / \mathrm{kg}$ twice daily for 4 weeks each. In study 3 (patients aged 11-15 years), patients received tolterodine extended-release capsules 2, 4, and $6 \mathrm{mg}$ once daily for 4 weeks each. Tolterodine was well tolerated, and there was no apparent relationship between tolterodine dosage and adverse events in any study [77].

In another group of children with $\mathrm{NB}$ and DO, tolterodine received orally in a dosage of $0.1 \mathrm{mg} / \mathrm{kg}$ daily, divided into two doses, was better tolerated than, and 
equally effective as, the standard drug oxybutynin chloride [78]. In a multicenter, open-label, double-blind, placebocontrolled study, long-term treatment with tolterodine ER was well tolerated in children aged 5-11 years [79].

Medhi et al. examined the efficacy, safety, and tolerability of tolterodine in children in comparison with oxybutynin treatment as demonstrated in randomized clinical trials and other studies. The dose of tolterodine used in different settings ranged from 0.5 to $8 \mathrm{mg} /$ day. Both ER and IR preparations of tolterodine were shown to have comparable efficacy. Tolterodine proved to have comparable efficacy with better tolerability than oxybutynin in these studies [80-84].

\subsubsection{Propiverine}

Another antimuscarinic drug is propiverine. Propiverine hydrochloride, with its anti-muscarinic and calcium-channel modulating properties, has been of proven efficacy in patients with nDO, including children and adolescents, and even in some of those cases unresponsive to other anticholinergics, with a low incidence rate $(<1.5 \%)$ of adverse events [85]. It was also evaluated during long-term treatment of children with $\mathrm{NB}$ at a dosage of $0.7-0.8 \mathrm{mg} / \mathrm{kg}$ body weight/day. Some studies demonstrated the superior tolerability of propiverine over oxybutynin, with comparable efficacy in children [74, 86-88]. In children and adolescents with IDO or nDO, propiverine was generally more effective and better tolerated than oxybutynin and provides a valuable option for the treatment of DO [89-91].

\subsubsection{Trospium}

Lopez Pereira et al. assessed the efficacy and dosage of trospium chloride $10,15,20$, or $25 \mathrm{mg}$ for managing bladder overactivity in 58 children compared with a placebo. Trospium was effective and well tolerated, although $10 \%$ of patients showed adverse effects [92]. In another uncontrolled study from 2001, the efficacy of trospium was assessed in children with NB. A group of 14 patients received trospium $15-45 \mathrm{mg}$ administered three times per day. During therapy, urodynamic investigations showed a significant increase in bladder capacity. The therapy was also well tolerated. A definite recommendation for the use of trospium chloride in children cannot be given due to insufficient data. However, preliminary results indicate that its use may have potential advantages in children [93].

\subsubsection{Solifenacin (Vesicare)}

At least two antimuscarinic drugs, darifenacin and solifenacin, with selective M3 receptor antagonist action and fewer systemic anticholinergic side effects than currently available agents, are yet to be studied in children [94]. Solifenacin is a tertiary amine with excellent bioavailability and a long half-life, and potentially a superior sideeffect profile due to M3 subtype receptor selectivity [95]. The efficacy and safety of solifenacin $1.25-10 \mathrm{mg}$ in the treatment of 244 children with non-neurogenic DO and NB refractory to oxybutynin or tolterodine was evaluated by Nadeau et al. In this non-randomized uncontrolled study, high subjective and objective success rates were maintained over a longer follow-up with an adjusted-dose regimen of solifenacin. A very interesting observation was that, even if more than half of the children required an adult dose of solifenacin, most of the adverse effects were acceptably low in frequency, of minor severity, and selflimiting [72, 96].

Solifenacin pediatric drug trials are finished and the drug is now waiting for review and approval from the US FDA.

\subsubsection{Fesoterodine and Darifenacin}

Data regarding fesoterodine and darifenacin therapy in children with NB are lacking.

\subsection{Alternative Route of Administration of Antimuscarinic Drugs}

\subsubsection{Intravesical Oxybutynin Instillation}

As an alternative route of administration, intravesical and transdermal oxybutynin has also been evaluated for its potential to decrease the side effects by reducing metabolism in the liver while maintaining systemic efficacy and bioavailability. Oxybutynin is available formulated for intravesical administration. As the majority of children with NB are on CIC, intravesical drug instillation seems to be a reliable method of treatment. This route of drug delivery will of course be very disputable in children with recurrent urinary tract infections and should be avoided in children with known VUR.

It was demonstrated that a reduced first-pass metabolism of oxybutynin after intravesical instillation resulted in reduced generation of the $\mathrm{N}$-desethyl metabolite. This may explain the clinically relevant reduction of systemic side effects of intravesical oxybutynin compared with oral therapy [97].

Some research showed that intravesically administered oxybutynin, apart from blocking muscarinic receptors in the bladder wall, acts by blocking the bladder cooling reflex mediated by $\mathrm{C}$-fibers in patients with an incomplete neurogenic lesion and DO [98].

It has been reported to be effective in suppressing DO with low incidence of side effects in children and adult patients with NB. In most studies, children with NB 
received oxybutynin $10 \mathrm{mg}$ daily (range $10-20 \mathrm{mg} /$ day or $0.1-0.2 \mathrm{~kg} /$ day) instilled into the bladder with a urethral catheter. Intravesical oxybutynin was shown to be a safe and effective therapeutic option for children with NB who experienced intolerable side effects or were unresponsive to oral antimuscarinics. However, adverse effects such as cognitive impairment can also occur in children treated in this way and patients must be closely monitored because these effects may differ from those had with oral administration $[7,45,54,57,97,99,100]$.

Intravesical instillation of oxybutynin is an accepted and effective treatment in children with neuropathic bladdersphincter dysfunction, when oral oxybutynin results in inadequate suppression of DO or intolerable side effects. In a study by Humblet et al., intravesical oxybutynin provided more than adequate suppression of detrusor activity, without side effects, over a period of 15 years [38].

The most commonly reported side effects after intravesical instillation of oxybutynin include dry mouth, facial flushing, constipation, blurred vision, and orthostatic hypotension or dizziness. Discontinuation of treatment due to side effects was reported in 28 patients $(9 \%)$, and an additional 38 patients (13\%) were reported to have withdrawn due to other causes [7].

\subsubsection{Intravesical Atropine Instillation}

Atropine is a cheap and easily obtainable antimuscarinic drug [101]. In 1993, Ekström et al. described improvement in six of eighteen patients with NB treated with intravesical atropine instillations. Others also observed improvement with no side effects after the intravesical instillation of atropine [102-104]. Similar data were also obtained in children with NB and DO treated with $10^{-6}$ solution of atropine; six of twelve improved in bladder capacity, with no side effects [105]. In a study of 57 patients with multiple sclerosis, intravesical atropine was as effective as oral oxybutynin for increasing bladder capacity, with fewer antimuscarinic side effects. It was concluded that intravesical atropine should be made available to patients with neurogenic detrusor overactivity requiring intermittent catheterization as an alternative to oral therapy [106].

\subsubsection{Transdermal Patch}

Transdermal delivery mechanisms may offer increased tolerability and patient acceptability whilst maintaining efficacy. It is available as a patch that is changed every 3-4 days, a gel available in individual sachets, or via a metered-dose pump that is applied daily. Transdermal oxybutynin has been compared with placebo and with tolterodine. Transdermal oxybutynin significantly reduced incontinence episodes and increased volume voided.
Therapy was effective in reducing the number of adverse effects related with antimuscarinic therapy, but it was associated with significant skin site reactions. In a study of 35 children with $\mathrm{OAB}$, with a mean age of 8 years, $97 \%$ reported good symptom response. The main side effect was skin irritation in $35 \%$ of participants, leading to discontinuation in $20 \%$ [107-110].

\subsection{B3-Adrenoceptor Agonist-Mirabegron (Betmiga)}

Mirabegron has been developed for the treatment of DO. Mirabegron is a $\beta 3$-adrenoceptor agonist. The $\beta 3$-adrenoceptor plays a role in the relaxation of the detrusor smooth muscle. Mirabegron relaxes the detrusor smooth muscle during the storage phase by activation of $\beta 3$ receptors, which increases bladder capacity $[111,112]$. Cytochrome P4503A4 is the primary isoenzyme responsible for the hepatic oxidative metabolism of mirabegron in vitro, with the CYP2D6 isoenzyme playing a minor role. Mirabegron is cleared by multiple metabolic enzymes, with no single enzyme being dominant [113].

In randomized trials, Mirabegron 25- and 50-mg tablets were superior to placebo for improved voiding outcomesurgency and incontinence episodes. It was also better tolerated than placebo [114-119]. Mirabegron also appeared as a safe and effective alternative for children with $\mathrm{OAB}$ refractory to antimuscarinics. In a study by Blais et al., a total of 58 patients with a median age of 10.1 years were on mirabegron $25-50 \mathrm{mg}$ for a median of 11.5 months. Median bladder capacity increased from $150 \mathrm{~mL}$ to $200 \mathrm{~mL}$ with continence improvement in 52 of 58 children. Eight of the patients reported mild or moderate side effects $[120,121]$. In a group of 39 children with NB, non-NB dysfunctions, and DO, patients received mirabegron 50-mg tablets with dosage depending on body weight: patients $<20 \mathrm{~kg}$ received $12.5-25 \mathrm{mg}$ once a day; patients 20-40 kg received $25-50 \mathrm{mg}$ once a day; patients $>40 \mathrm{~kg}$ received $50 \mathrm{mg}$ once a day. Mirabegron was effective in $82 \%$ of children, increasing bladder capacity and decreasing urine incontinence, with no serious side effects. (Kroll P., unpublished data).

Also, in recent study on two off-label antimuscarinic drugs administrated in children with DO, mirabegron with solifenacin were effective and well tolerated [121].

\subsection{Double Anticholinergic Therapy}

It was also shown that in children with refractory DO, double anticholinergic therapy is an efficient and serious alternative. Combinations of oxybutynin and/or solifenacin and/or trospium and/or tolterodine were tested in several studies [121-125]. 
In a group of 33 children with NB using two anticholinergic medications simultaneously (oxybutynin 10-30 mg, tolterodine $4 \mathrm{mg}$, and/or solifenacin 5-10 mg), Bolduc et al. optimized the medical therapy for children in whom single-agent anticholinergic therapy failed. Continence improved in all patients. No, mild or moderate side effects were reported by 12,16 , and 5 patients, respectively [122]. Also, adding mirabegron to solifenacin appears to be a safe alternative for children with refractory overactive bladder. Dual therapy is well tolerated and the adjusted dose regimen appears safe [121].

\subsection{Botulinum Toxin-A}

For several years, Botulinum toxin-A (BTX) has been successfully used in neuromuscular diseases associated with an increased muscular tension. It is administered to extremity muscles in children with spastic forms of cerebral palsy and is also used in the treatment of torticollis, blepharospasm, and in aesthetic surgery. Efficacy of BTX has been well documented in patients with either NB or non-neurogenic voiding dysfunctions. Less frequent have been reports on efficacy of BTX in the treatment of NB in children. In urology, BTX has been used mainly to inject the detrusor muscle in order to abolish DO, but it has also been applied to overactive sphincters. Efficacy of injections to the detrusor in children with DO has been noted in $60-80 \%$ of children with NB. BTX is available in various preparations, but only one, onabotulinum (Botox), has formal registration for cystoscopic treatment of patients with NB and DO. There are also reports on abobotulinum (Dysport) injections in children with NB, but only onabotulinum has been investigated in properly powered, multicenter, randomized controlled trials for the treatment of nDO and urinary incontinence [126-128].

The optimal dosage of BTX both in children and adolescents is still under discussion. Some authors have shown no clear dose-related effect for either onabotulinum or abobotulinum. In adults, intradetrusor application of BTX has been reported at a dosage of 100-300 units of onabotulinum or 500-1500 units of abobotulinum per patient. In children with NB, 2.5-12 units/kg bodyweight of onabotulinum or $10-30$ units $/ \mathrm{kg}$ bodyweight of abobotulinum have been used [126-131].

In children with $\mathrm{NB}$ and DO, the toxin is administered in divided doses into 20-30 sites of the bladder dome. BTX activity in the urinary bladder persists for 6-9 months, and can then be repeated. Repeated intradetrusor BTX injections have been found to be just as effective as the first application [129, 132, 133].

Endoscopic administration of BTX should be considered as an alternative method in cases of overactive NB where there is lack of efficacy with or side effects from oral antimuscarinic treatment, or lack of parental consent to surgical treatment (cystostomy, intestinal bladder augmentation).

If it is considered to be an alternative to surgery, then the obvious limitation of BTX therapy is the transient effect of the endoscopic procedure. Although many questions remain regarding the optimal use of this minimally invasive option for urologic applications, the opportunity for expanding indications will provide urologists with more options for addressing difficult challenges in voiding dysfunction.

\section{$10 \propto$-Blockers}

Ineffective voiding is one of the principal problems in a child with NB. The sympathetic part of the autonomic nervous system is primarily responsible for urine continence in the bladder. In the sphincter and bladder neck muscles, a prevalence of $\alpha 1$-andregenic receptors is found. Their activation increases the sphincter mechanism tension, and inactivation enables voiding [134, 135].

The consequence of increased sphincter activity is the storage of urine in the bladder at high pressures and its leakage from the bladder only if the pressure exceeds values considered harmful to the kidneys. Urodynamic examinations are essential for the assessment of LUT functioning. Of greatest significance in children with NB is determining the value of leak point pressure (LPP). LPP $>40 \mathrm{~cm} \mathrm{H} \mathrm{H}_{2} \mathrm{O}$ is considered dangerous [28-30].

Even if a child with NB is urinating, lack of CNS control over the urinary tract elements results in detrusor-sphincter dyscoordination: during bladder contraction, no sphincter relaxation is observed, creating the subvesical obstruction. Micturition is ineffective and urine stream is weak, irregular, or interrupted with significant residual urine.

$\alpha_{1}$-Adrenergic receptors are dominant in the sphincter muscles and urinary bladder neck muscles. Activation of these receptors increases activity of the $\alpha$-adrenergic part of the autonomic nervous system and sphincter tension, assisting in the maintenance of urinary continence. Since the 1970s, $\alpha$-blockers have been used to reduce increased sphincter tension and to eliminate subvesical functional obstruction. $\alpha$-Blockers act through periodic, reversible blocking of $\alpha_{1}$-adrenergic receptors in the muscles of the bladder neck and urethra sphincters [136-138].

Several preparations are available in the group of $\alpha$ blockers: non-selective preparations like phenoxybenzamine (Dibenzyline) or $\alpha_{1}$-selective drugs such as prazosin (Minipress), terazosin (Hytrin), silodosin (Rapaflo), alfuzosin (Dalfaz), doxazosin (Doxar), and tamsulosin (Omnic). None of those drugs were approved for usage in children, so treatment with any $\alpha$-blocker is off-label. 
The efficacy of selective $\alpha$-blockers in patients with subvesical obstruction caused by benign prostatic hypertrophy is well documented [139, 140]. There are few reports on the use of $\alpha$-blockers in patients with NB, fewer dealing with children with NB or non-NB dysfunctions. Data from those studies are conflicting, showing a variable degree of efficacy when using selective $\alpha_{1}$-blockers in children with NB and non-NB dysfunctions.

First, phenoxybenzamine was described as effective in patients with NB and subvesical obstruction [136, 137]. In 1976, de Voogt and van der Sluis confirmed the usefulness of $\alpha$-blockers in children with NB with outflow resistance, especially if detrusor activity was absent [141]. In an uncontrolled study of 17 children with NB from 2002, Schulte-Baukloh et al. showed that alfuzosin decreases the DLPP significantly, and should be considered an alternative or addition to intermittent catheterization in selected patients [142]. One year later, Abrams et al. [143] showed the efficacy and safety of tamsulosin treatment in patients with NB due to suprasacral spinal cord injury; in another study, Kakizaki et al. proved tamsulosin reduced functional urethral resistance during voiding and improved flow rate in 24 patients with NB [144]. In the same year, Cain et al. reported on 55 children with a mean age of 7.9 years diagnosed with increased post-void residual (PVR), treated with doxazosin. Therapy was effective with $88 \%$ reduction in residual urine. The conclusion was that $\alpha$-blocker therapy might be used as either a replacement for or in addition to biofeedback in patients with urinary retention [145]. Two years later, in a comparative study of 28 children with a mean age of 6.25 years, Yucel et al. showed that doxazosin therapy seems to be an alternative to biofeedback in dysfunctional voiding in children with urinary retention [146]. In a placebo-controlled study, doxazosin decreased the number of incontinent episodes weekly and improved the dysfunctional voiding scores over placebo, but the differences were not statistically significant [147].

In a comparative, non-placebo controlled study of 60 children with ineffective voiding and significant PVR, both methods (oral doxazosin therapy vs behavioral treatment and rehabilitation [standard urotherapy]) showed similar effectiveness [148]. Also, Gołębiewski reported significant improvement in effectiveness of bladder emptying (PVR decreased to a mean of $12 \mathrm{~mL}$, compared with $74 \mathrm{~mL}$ before treatment) in a group of 208 children with nonneurogenic voiding dysfunctions treated with doxazosin [149].

In the study by Abraham et al. on children with significant PVR urine after posterior urethral valve ablation, another $\alpha_{1}$-blocker, terazosin, has proved to be safe and results in significant reduction in residual urine [150]. In the study from 2009 on children with mean age 8.9 years (range 5-16), the most selective $\alpha_{1}$-blocker, tamsulosin, proved to be a safe and effective treatment option for LUT symptoms in children with voiding dysfunctions [151]. In another group of children treated with tamsulosin, Van Batavia et al. showed that $\alpha_{1}$-blocker therapy continued to benefit children with primary bladder neck dysfunction even after a longer period of time [152]. Data from a randomized trial on tamsulosin in 135 children with NB were very interesting: although $51(37.8 \%)$ patients were LPP 'responders', no statistically significant difference was found in LPP response rates between tamsulosin and placebo groups [153].

A similar observation of the significant decrease in LPP in some patients, along with the lack of significant efficacy of $\alpha$-blockers in the whole study group of children with NB treated with selective $\alpha$-blockers, was reported recently [154].

\subsection{Dosage of $\alpha$-Blockers}

Several published papers have proposed a variety of dosage regimens for $\alpha$-blockers, mainly starting with a quarter of the appropriate adult dosage.

In a study from 2004 in a group of 30 children treated with doxazosin, an old rule of calculating off-label drugs was adopted and the following regimen was proposed with dosage depending on body weight: for patients $>40 \mathrm{~kg}$, adult dosage of $2.0 \mathrm{mg}$ once a day; in children $20-40 \mathrm{~kg}$, $1.0 \mathrm{mg}$; and for children $<20 \mathrm{~kg}, 0.5-1.0 \mathrm{mg}$ once a day was recommended [155]. In other studies, the initial dose of doxazosin in children was $0.5-2.0 \mathrm{mg}$ once daily [145-149, 156, 157], or $0.03 \mathrm{mg} / \mathrm{kg}$ bodyweight/day [154, 158]. For terazosin, a starting dose of $0.5 \mathrm{mg}$ increasing to $2 \mathrm{mg}$ was proposed [143, 159]. In the study by VanderBrink et al., in children with a mean age of 8.9 years, an initial dose of tamsulosin $0.2 \mathrm{mg}$ was given once a day, increasing to $0.4 \mathrm{mg}$. The authors concluded that a dose of $0.4 \mathrm{mg}$ was safe and necessary in the majority of patients [151]. In another study, 51 children with a mean age of 11.6 years (range 3.5-17.8) were also taking tamsulosin at a mean dose of $0.4 \mathrm{mg}$ (range $0.2-0.8 \mathrm{mg}$ ) [152]. Alfuzosin was used to decrease the elevated DLPP in 17 children with NB (mean age 6.3 years) in an oral formulation (2.5-7.5 mg/day) [142].

\section{$10.2 \propto$-Blocker Side Effects}

Importantly, when prescribed off-label, there were no reports of serious adverse events associated with $\alpha$-blocker treatment in children. To date, no serious adverse events have been reported in relation to $\alpha$-blocker therapy in children with NB.

In the biggest study of 208 children with bladder dysfunctions treated with $\alpha$-blockers, minor side effects were 
observed in only five children [149]. In another study of 55 patients also treated with doxazosin, minor side effects were observed in two children, and in another group of 16 boys there were no significant adverse effects. Decreases of systolic and diastolic blood pressure were negligible $[145,156]$. In a group of 17 children 3-15 years old treated with $0.5-1.0 \mathrm{mg}$ doxazosin, only one patient had mild postural hypotension, which resolved with dose reduction [157]. In another study of 14 children, one boy who experienced drowsiness and a decrease in blood pressure failed to complete the study [154]. In another study of 28 patients receiving doxazosin, no drug-related side effects were reported [146]. In a comparative study of 60 children, 30 children with a mean age of 9.2 years were treated with doxazosin $0.5-2 \mathrm{mg}$. Side effects were noted in six children, and included headache and vertigo related to hypotension, with epistaxis in two children. None of those children stopped $\alpha$-blocker therapy [148].

In the group of 51 children treated with tamsulosin, no patient had any major side effects; blood pressure and heart rate remained normal in all children, and only two patients reported light-headedness and somnolence-in neither patient were the side effects bothersome enough to stop the medication. In another group of 23 children followed for 20 months, tamsulosin demonstrated no clinically significant effect on blood pressure [151, 152].

Alfuzosin therapy was also well tolerated; side effects were rare and not severe [142]. In a study of 42 children after posterior urethral valve ablation, only one patient reacted to terazosin, with hypotension necessitating its withdrawal [150].

\subsection{Other Drugs}

There is no evidence that any pharmacotherapy is effective in children with NB and areflectic detrusor. There is no data that any drug is able to improve sphincter function in children with NB and sphincter inactivity.

\section{Conclusions}

In conclusion, it should be stated that there is enough evidence on the benefit of pharmacological decrease of elevated detrusor pressure in children with $\mathrm{NB}$, but unfortunately only one drug is currently approved for children. There is no doubt that urological pharmacology has some valuable drugs to offer for children with $\mathrm{nDO}$, but they have yet to be evaluated in the proper manner in prospective studies. Theoretically, pharmacotherapy with selective $\alpha$-blockers should be of benefit for children with NB and elevated LPP. However, at present there is no evidential proof of their action on sphincters in children with NB. A lack data from prospective, multicenter, randomized, placebo-controlled studies is evident, but some studies (i.e., tamsulosin, alfuzosin and mirabegron) in children with NB have been started [160].

\section{Compliance with Ethical Standards}

Conflict of interest The author (PK) declares that there are no conflicts of interest.

Declaration of funding interests No sources of funding were used to support the writing of this article. Open access funding was provided through an agreement between SpringerNature and the Polish Ministry of Science and Higher Education.

Open Access This article is distributed under the terms of the Creative Commons Attribution-NonCommercial 4.0 International License (http://creativecommons.org/licenses/by-nc/4.0/), which permits any noncommercial use, distribution, and reproduction in any medium, provided you give appropriate credit to the original author(s) and the source, provide a link to the Creative Commons license, and indicate if changes were made.

\section{References}

1. Rackley R, Vasavada SP, Firoozi F, Ingber MS. Neurogenic bladder. eMedicine 2009. http://emedicine.medscape.com/ article/453539-overview\#showall. Accessed March 2017.

2. Fowler CJ, Griffiths D, de Groat WC. The neural control of micturition. Nat Rev Neurosci. 2008;9:453-66.

3. Marshall DF, Boston VE. Does bladder capacity assessment by frequency/volume chart correlate well with urodynamic estimation in children with spina bifida? Eur J Pediatr Surg. 2001;11(Suppl 1):S24-7.

4. Wen JG, Tong EC. Cystometry in infants and children with no apparent voiding symptoms. Br J Urol. 1998;81:468-73.

5. Hjälmås K. Urodynamics in normal infants and children. Scand J Urol Nephrol Suppl. 1988;114:20-7.

6. Austin PF, Bauer SB, Bower W, Chase J, Franco I, Hoebeke P, Rittig S, Vande Walle J, von Gontard A, Wright A, Yang SS, Neveus T. The standardization of terminology of lower urinary tract function in children and adolescents: update report from the standardization committee of the international children's continence society. Neurourol Urodynam. 2016;35:471-81.

7. Kroll P, Zachwieja J. Complications of untreated and ineffectively treated neurogenic bladder dysfunctions in children: our own practical classification. Eur Rev Med Pharmacol Sci. 2016;20:1229-37.

8. Ruffion A, Castro-Diaz D, Patel H, Khalaf K, Onyenwenyi A, Globe D, Lereun C, Teneishvili M, Edwards M. Systematic review of the epidemiology of urinary incontinence and detrusor overactivity among patients with neurogenic overactive bladder. Neuroepidemiology. 2013;41:146-55.

9. Snow-Lisy DC, Yerkes EB, Cheng EY. Update on urological management of spina bifida from prenatal diagnosis to adulthood. J Urol. 2015;194:288-96.

10. Pannek J, Blok B, Castro-Diaz D, Del Popolo G, Kramer G, Radziszewski P, Reitz A, Stöhrer M, Wyndaele J-J. EAU Guidelines on Neurogenic Lower Urinary Tract Dysfunction. https://uroweb.org/wp-content/.../20_Neurogenic-LUTD_LR. Accessed March 2017.

11. Bauer SB. Neurogenic bladder: etiology and assessment. Pediatr Nephrol. 2008;23:541-51. 
12. Sturm RM, Cheng EY. The management of the pediatric neurogenic bladder. Curr Bladder Dysfunct Rep. 2016;11:225-33.

13. Demir AD, Gursoy AE, Goknar N, Uzuner S, Ozkaya E, Erenberk U, Vehapoglu A, Dundaroz MR, Oktem F. Evaluation of autonomic nervous system function in children with overactive bladder syndrome. Neurourol Urodyn. 2016. doi:10.1002/ nau. 22993.

14. Hubeaux K, Deffieux X, Raibaut P, Le Breton F, Jousse M, Amarenco G. Evidence for autonomic nervous system dysfunction in females with idiopathic overactive bladder syndrome. Neurourol Urodyn. 2011;30:1467-72.

15. Franco I. Pediatric overactive bladder syndrome: pathophysiology and management. Paediatr Drugs. 2007;9:379-90.

16. Kondo A, Kamihira O, Ozawa H. Neural tube defects: prevalence, etiology and prevention. Int J Urol. 2009;16:49-57.

17. Amini H, Axelsson O, Ollars B, Anneren G. The Swedish Birth Defects Registry: ascertainment and incidence of spina bifida and cleft lip/palate. Acta Obstet Gynecol Scand. 2009;88:654-9.

18. Silveri M, Capitanucci ML, Capozza N, Mosiello G, Silvano A, Gennaro MD. Occult spinal dysraphism: neurogenic voiding dysfunction and long-term urologic follow-up. Pediatr Surg Int. 1997; 12:148-50.

19. Reiner I, Jones M, Donnell S, Rickwood AM. Incidence of normal micturition in myelomeningocele patients. Arch Dis Child. 1992;67:640-1.

20. Jørgensen B, Olsen LH, Jørgensen TM. Long-term follow-up in spinal dysraphism: outcome of renal function and urinary and faecal continence. Scand J Urol Nephrol. 2010;44:95-100.

21. Lee NG, Gomez P, Uberoi V, Kokorowski PJ, Khoshbin S, Bauer SB, Estrada CR. In utero closure of myelomeningocele does not improve lower urinary tract function. J Urol. 2012;188:1567-71.

22. Brock JW, Carr MC, Adzick NS, Burrows PK, Thomas JC, Thom EA, Howell LJ, Farrell JA, Dabrowiak ME, Farmer DL, Cheng EY, Kropp BP, Caldamone AA, Bulas DI, Tolivaisa S, Baskin LS, Moran M, Koh J, Champeau A, Arnhym A, Ryan T, Perry R, Trusler L, Perry T, Musok EG, Holloway K, Spong CY, Higgins R. Bladder function after fetal surgery for myelomeningocele. Pediatrics. 2015;136:906-13.

23. Clayton DB, Tanaka ST, Trusler L, Thomas JC, Pope JC 4th, Adams MC, Brock JW 3rd. Long-term urological impact of fetal myelomeningocele closure. J Urol. 2011;186:1581-5.

24. Holzbeierlein J, Pope JC IV, Adams MC, Bruner J, Tulipan N, Brock JW 3rd. The urodynamic profile of myelodysplasia in childhood with spinal closure during gestation. J Urol. 2000;164:1336-9.

25. Tarcan T, Bauer S, Olmedo E, Khoshbin S, Kelly M, Darbey M. Long-term followup of newborns with myelodysplasia and normal urodynamic findings: is followup necessary? J Urol. 2001;165:564-7.

26. Mitra A, Bajpa M, Gupta A, Sharma N, Panda SS. Modern management of neurogenic bladder: making the child the focus of therapeutic efforts. J Progr Paediatr Urol. 2014;17:15-23.

27. Madersbacher $\mathrm{H}$. The various types of neurogenic bladder dysfunction: an update of current therapeutic concepts. Paraplegia. 1990;28:217-29.

28. McGuire EJ, Woodside JR, Bordin TA, Weiss RM. Prognostic value of urodynamic testing in myelodysplastic patients. J Urol. 1981;136:205-9.

29. Bauer SB, Hallet M, Khoshbin S, Lebowitz RL, Winston KR, Gibson S, Colodny AH, Retik AB. Predective value of urodynamic evaluation in newborns with myelodysplasia. JAMA. 1984;252:650-65.

30. Stein R, Assion C, Beetz R, Bürst M, Cremer R, Ermert A, Goepel M, Kuwertz-Bröking E, Ludwikowski B, Michael T, Pannek J, Peters H, Rohrmann D, Rübben I, Schröder A,
Trollmann R, Thüroff JW, Wagner W. Neurogene Blasenfunktions-störungen bei Patienten mit Meningomyelozele. Urologe A. 2015;54:239-53.

31. Gerridzen RG, Thijssen AM, Dehoux E. Risk factors for upper tract deterioration in chronic spinal cord injury patients. J Urol. 1992;147:416-8.

32. Mourtzinos A, Stoffel JT. Management goals for the spina bifida neurogenic bladder: a review from infancy to adulthood. Urol Clin North Am. 2010;37:527-35.

33. Baek M, Kang JY, Jeong J, Kim DK, Kim KM. Treatment outcomes according to neuropathic bladder sphincter dysfunction type after treatment of oxybutynin chloride in children with myelodysplasia. Int Urol Nephrol. 2013;45:703-9.

34. Haab F. Chapter 1: The conditions of neurogenic detrusor overactivity and overactive bladder. Neurourol Urodyn. 2014;33(Suppl 3):S2-5.

35. Chancellor MB, Anderson RU, Boone TB. Pharmacotherapy for neurogenic detrusor overactivity. Am J Phys Med Rehabil. 2006;85:536-45.

36. Chang CK, Wong TT, Huang BS, Chan RC, Yang TF. Spinal dysraphism: a cross-sectional and retrospective multidisciplinary clinic-based study. J Chin Med Assoc. 2008;71:502-8.

37. Tiryaki S, Yagmur I, Parlar Y, Ozel K, Akyildiz C, Avanoglu A, Ulman I: Botulinum injection is useless on fibrotic neuropathic bladders. J Pediatr Urol. 2015;11:27.e1-4.

38. Humblet M, Verpoorten C, Christiaens MH, Hirche H, Jansen K, Buyse G, van Gool JD. Long-term outcome of intravesical oxybutynin in children with detrusor-sphincter dyssynergia: with special reference to age-dependent parameters. Neurourol Urodyn. 2015;34:336-42.

39. Guerra LA, Moher D, Sampson M, Barrowman N, Pike J, Leonard M. Intravesical oxybutynin for children with poorly compliant neurogenic bladder: a systematic review. J Urol. 2008;180:1091-7.

40. Landau EH, Jayanthi VR, Churchill BM, Shapiro E, Gilmour RF, Khoury AE, Macarak EJ, McLorie GA, Steckler RE, Kogan BA. Loss of elasticity in dysfunctional bladders: urodynamic and histochemical correlation. J Urol. 1994;152:702-5.

41. Elbadawi A, Resnick NM, Dörsam J, Yalla SV, Haferkamp A. Structural basis of neurogenic bladder dysfunction. I. Methods of prospective ultrastructural study and overview of the findings. J Urol. 2003;169:540-6.

42. Snodgrass WT, Gargollo PC. Urologic care of the neurogenic bladder in children. Urol Clin North Am. 2010;37:207-14.

43. Edelstein RA, Bauer SB, Kelly MD, Darbey MM, Peters CA, Atala A, Mandell J, Colodny AH, Retik AB. The long-term urological response of neonates with myelodysplasia treated proactively with intermittent catheterization and anticholinergic therapy. J Urol. 1995;154:1500-4.

44. Dik P, Klijn AJ, van Gool JD, de Jong-de Vos van Steenwijk CC, de Jong TP. Early start to therapy preserves kidney function in spina bifida patients. Eur Urol. 2006;49:908-13.

45. Kasabian NG, Bauer SB, Dyro FM, Colodny AH, Mandell J, Retik AB. The prophylactic value of clean intermittent catheterization and anticholinergic medication in newborns and infants with myelodysplasia at risk of developing urinary tract deterioration. Am J Dis Child. 1992;146:840-3.

46. Lapides J, Diokno AC, Silber SJ, Lowe BS. Clean intermittent self-catheterization in the treatment of urinary tract disease. J Urol. 1972;107:458-61.

47. Kessler TM, Lackner J, Kiss G, Rehder P, Madersbacher H. Early proactive management improves upper urinary tract function and reduces the need for surgery in patients with myelomeningocele. Neurourol Urodyn. 2006;25:758-62.

48. Anderson KE. The overactive bladder: pharmacologic basis of drug treatment. Urology. 1997;50:74-89. 
49. Nabi G, Cody JD, Ellis G, Herbison P, Hay-Smith J. Anticholinergic drugs versus placebo for overactive bladder syndrome in adults. Cochrane Database Syst Rev. 2006;(4):CD003781.

50. Guay DR. Clinical pharmacokinetics of drugs used to treat urge incontinence. Clin Pharmacokinet. 2003;42:1243-85.

51. Andersson KE, Chapple CR. Oxybutynin and the overactive bladder. World J Urol. 2001;19:319-23.

52. Wein AJ, Rackley RR. Overactive bladder: a better understanding of pathophysiology, diagnosis and management. J Urol. 2006;175:5-10.

53. Finney SM, Andersson KE, Gillespie JI, Stewart LH. Antimuscarinic drugs in detrusor overactivity and the overactive bladder syndrome: motor or sensory actions? BJU Int. 2006;98:503-7.

54. Hsu CC, Chuang YC, Chancellor MB. Intravesical drug delivery for dysfunctional bladder. Int J Urol. 2013;20:552-62.

55. Blais AS, Bergeron M, Nadeau G, Ramsay S, Bolduc S. Anticholinergic use in children: persistence and patterns of therapy. Can Urol Assoc J. 2016;10:137-40.

56. Park SJ, Pai KS, Kim JM, Park K, Kim KS, Song SH, Park S, Kim SO, Ryu DS, Baek M, Lee SD, Lee JW, Im YJ, Han SW, Chung JM, Cho MH, Ha TS, Cho WY, Suh HJ, Korean Children's Continence and Enuresis Society. Efficacy and tolerability of anticholinergics in Korean children with overactive bladder: a multicenter retrospective study. J Korean Med Sci. 2014;29:1550-4.

57. Ferrara P, D'Aleo CM, Tarquini E, Salvatore S, Salvaggio E. Side-effects of oral or intravesical oxybutynin chloride in children with spina bifida. BJU Int. 2001;87:674-8.

58. Benner JS, Nichol MB, Rovner ES, Jumadilova Z, Alvir J, Hussein M, Fanning K, Trocio JN, Brubaker L. Patient-reported reasons for discontinuing overactive bladder medication. BJU International. 2010;105:1276-82.

59. Wagg A, Compion G, Fahey A, Siddiqui E. Persistence with prescribed antimuscarinic therapy for overactive bladder: a UK experience. BJU Int. 2012;110:1767-74.

60. Gish P, Mosholder AD, Truffa M, Johann-Liang R. Spectrum of central anticholinergic adverse effects associated with oxybutynin: comparison of pediatric and adult cases. J Pediatr. 2009;155:432-4.

61. Giramonti KM, Kogan BA, Halpern LF. The effects of anticholinergic drugs on attention span and short-term memory skills in children. Neurourol Urodyn. 2008;27:315-8.

62. Veenboer PW, Huisman J, Chrzan RJ, Kuijper CF, Dik P, de Kort LM, de Jong TP. Behavioral effects of long-term antimuscarinic use in patients with spinal dysraphism: a case control study. J Urol. 2013;190:2228-32.

63. Kinlaw AC, Jonsson Funk M, Steiner MJ, Conover MM, Pate V, Wu JM. Trends in pharmacotherapy for bladder dysfunction among children in the United States, 2000 to 2013. Clin Pediatr. 2016. doi:10.1177/0009922816641366.

64. Madhuvrata P, Cody JD, Ellis G, Herbison GP, Hay-Smith EJ: Which anticholinergic drug for overactive bladder symptoms in adults. Cochrane Database Syst Rev. 2012;18(1):CD005429.

65. Buser N, Ivic S, Kessler TM, Kessels AG, Bachmann LM. Efficacy and adverse events of antimuscarinics for treating overactive bladder: network meta-analyses. Eur Urol. 2012;62:1040-60.

66. Novara G, Galfano A, Secco S, D’Elia C, Cavalleri S, Ficarra V, Artibani W. A systematic review and metaanalysis of randomized controlled trials with antimuscarinic drugs for overactive bladder. Eur Urol. 2008;54:740-64.

67. Todorova A, Vonderheid-Guth B, Dimpfel W. Effects of tolterodine, trospiumchloride, and oxybutynin on the central nervous system. J Clin Pharmacol. 2001;41:636-44.
68. Robinson D, Giarenis I, Cardozo L. New developments in the medical management of overactive bladder. Maturitas. 2013;76:225-9.

69. Waldeck K, Larsson B, Andersson KE. Comparison of oxybutynin and its active metabolite, $N$-desethyl-oxybutynin, in the human detrusor and parotid gland. J Urol. 1997;157:1093-7.

70. Noronha-Blob L, Kachur JF. Enantiomers of oxybutynin: in vitro pharmacological characterization at M1, M2 and M3 muscarinic receptors and in vivo effects on urinary bladder contraction, mydriasis and salivary secretion in guinea pigs. J Pharmacol Exp Ther. 1991;256:562-7.

71. Youdim K, Kogan BA. Preliminary study of the safety and efficacy of extended-release oxybutynin in children. Urology. 2002;59:428-32.

72. Nadeau G, Schröder A, Moore K, Genois L, Lamontagne P, Hamel M, Pellerin E, Bolduc S. Long-term use of solifenacin in pediatric patients with overactive bladder: extension of a prospective open-label study. Can Urol Assoc J. 2014;8:118-23.

73. Lee JH, Kim KR, Lee YS, Han SW, Kim KS, Song SH, Baek M, Park K. Efficacy, tolerability, and safety of oxybutynin chloride in pediatric neurogenic bladder with spinal dysraphism: a retrospective, multicenter, observational study. Korean J Urol. 2014;55:828-33.

74. Madersbacher H, Mürtz G, Alloussi S, Domurath B, Henne T, Körner I, Niedeggen A, Nounla J, Pannek J, Schulte-Baukloh H, Schultz-Lampel D, Bock P, Strugala G. Propiverine vs oxybutynin for treating neurogenic detrusor overactivity in children and adolescents: results of a multicentre observational cohort study. BJU Int. 2009;103:776-81.

75. Momper JD, Karesh A, Green DJ, Hirsch M, Khurana M, Lee J, Kim MJ, Mulugeta Y, Sachs HC, Yao L, Burckart GJ. Drug development for pediatric neurogenic bladder dysfunction: dosing, endpoints, and study design. J Clin Pharmacol. 2014;54:1239-46.

76. Reddy PP, Borgstein NG, Nijman RJ, Ellsworth PI. Long-term efficacy and safety of tolterodine in children with neurogenic detrusor overactivity. J Pediatr Urol. 2008;4:428-33.

77. Ellsworth PI, Borgstein NG, Nijman RJ, Reddy PP. Use of tolterodine in children with neurogenic detrusor overactivity: relationship between dose and urodynamic response. J Urol. 2005; 174:1647-51.

78. Goessl C, Sauter T, Michael T, Bergé B, Staehler M, Miller K. Efficacy and tolerability of tolterodine in children with detrusor hyperreflexia. Urology. 2000;55:414-8.

79. Nijman RJ, Borgstein NG, Ellsworth P, Siggaard C. Long-term tolerability of tolterodine extended release in children 5-11 years of age: results from a 12-month, open-label study. Eur Urol. 2007;52:1511-7.

80. Medhi B, Mittal N, Bansal D, Prakash A, Sarangi SC, Nirthi B. Comparison of tolterodine with standard treatment in pediatric patients with non-neurogenic dysfunctional voiding/over active bladder: a systematic review. Indian J Physiol Pharmacol. 2013;57:343-53.

81. Bolduc S, Upadhyay J, Payton J, Bägli DJ, McLorie GA, Khoury AE, Farhat W. The use of tolterodine in children after oxybutynin failure. BJU Int. 2003;91:398-401.

82. Hjälmas K, Hellström AL, Mogren K, Läckgren G, Stenberg A. The overactive bladder in children: a potential future indication for tolterodine. BJU Int. 2001;87:569-74.

83. Munding M, Wessells H, Thornberry B, Riden D. Use of tolterodine in children with dysfunctional voiding: an initial report. J Urol. 2001;165:926-8.

84. Reinberg Y, Crocker J, Wolpert J, Vandersteen D. Therapeutic efficacy of extended release oxybutynin chloride, and immediate release and long acting tolterodine tartrate in children with diurnal urinary incontinence. J Urol. 2003;169:317-9. 
85. Grigoleit U, Murtz G, Laschke S, Schuldt M, Goepel M, Kramer G, Stöhrer M. Efficacy, tolerability and safety of propiverine hydrochloride in children and adolescents with congenital or traumatic neurogenic detrusor overactivity: a retrospective study. Eur Urol. 2006;49:1114-20.

86. Schulte-Baukloh H, Mürtz G, Heine G, Austin P, Miller K, Michael T, Strugala G, Knispel HH. Urodynamic effects of propiverine in children and adolescents with neurogenic bladder: results of a prospective long-term study. J Pediatr Urol. 2012;8:386-92.

87. Madersbacher H, Mürtz G. Efficacy, tolerability and safety profile of propiverine in the treatment of the overactive bladder (nonneurogenic and neurogenic). World J Urol 2001;19:324-35.

88. Stöhrer M, Mürtz G, Kramer G, Schnabel F, Arnold EP, Wyndaele JJ. Propiverine compared to oxybutynin in neurogenic detrusor overactivity - results of a randomized, double-blind, multicenter clinical study. Eur Urol 2007;51:235-42.

89. McKeage K. Propiverine: a review of its use in the treatment of adults and children with overactive bladder associated with idiopathic or neurogenic detrusor overactivity, and in men with lower urinary tract symptoms. Clin Drug Investig. 2013;33:71-91.

90. Marschall-Kehrel D, Feustel C, Persson de Geeter C, Stehr M, Radmayr C, Sillén U, Strugala G. Treatment with propiverine in children suffering from nonneurogenic overactive bladder and urinary incontinence: results of a randomized placebo-controlled phase 3 clinical trial. Eur Urol. 2009;55:729-38.

91. Kim WJ, Lee DG, Lee SW, Lee YK, Lee JS, Park KH, Baek M. Efficacy and safety of propiverine in children with overactive bladder. Korean J Urol. 2012;53:275-9.

92. Lopez Pereira P, Miguelez C, Caffarati J, Estornell F, Anguera A. Trospium chloride for the treatment of detrusor instability in children. J Urol. 2003;170:1978-81.

93. Bürst M, Wolf A. Efficacy and safety of trospium chloride use in children with idiopathic and neurogenic detrusor overactivity: an overview of available data. Urotoday Int J. 2011;4(1):17.

94. Franco I. Functional bladder problems in children Pathophysiology, diagnosis, and treatment. Pediatr Clin $\mathrm{N}$ Am. 2012;59:783-817.

95. Smulders RA, Krauwinkel WJ, Swart PJ, Huang M. Pharmacokinetics and safety of solifenacin succinate in healthy young men. J Clin Pharmacol. 2004;44:1023-33.

96. Bolduc S, Moore K, Nadeau G, Lebel S, Lamontage P, Hamel M. Prospective open label study of solifenacin for overactive bladder in children. J Urol. 2010;184:1668-73.

97. Buyse G, Waldeck K, Verpoorten C, Björk H, Casaer P, Andersson KE. Intravesical oxybutynin for neurogenic bladder dysfunction: less systemic side effects due to reduced first pass metabolism. J Urol. 1998;160:892-6.

98. Van Meel TD, De Wachter S, Wyndaele JJ. The effect of intravesical oxybutynin on the ice water test and on electrical perception thresholds in patients with neurogenic detrusor overactivity. Neurourol Urodyn. 2010;29:391-4.

99. Amark P, Bussman G, Eksborg S. Follow-up of long-time treatment with intravesical oxybutynin for neurogenic bladder in children. Eur Urol. 1998;34:148-53.

100. Hayashi A, Saito M, Okada S, Hanada T, Watanabe T, Satoh K, Kanzaki S. Treatment with modified intravesical oxybutynin chloride for neurogenic bladder in children. J Pediatr Urol. 2007;3:438-42.

101. Deaney C, Glickman S, Gluck T, Malone-Lee JG. Intravesical atropine suppression of detrusor hyperreflexia in multiple sclerosis. J Neurol Neurosurg Psychiatry. 1998;65:957-8.

102. Ekström B, Andersson KE, Mattiasson A. Urodynamic effects of intravesical instillation of atropine and phentolamine in patients with detrusor hyperactivity. J Urol. 1993;149:155-8.
103. Glickman S, Tsokkos N, Shah PJ. Intravesical atropine and suppression of detrusor hypercontractility in the neuropathic bladder. A preliminary study. Paraplegia. 1995;33:36-9.

104. Enskat R, Deaney CN, Glickman S. Systemic effects of intravesical atropine sulphate. BJU Int. 2001;87:613-6.

105. Kroll P, Jankowski A. Intravesical instillation of atropine in treatment of detrusor overactivity in children. Wiad Lek. 1998;51:87-91.

106. Fader M, Glickman S, Haggar V, Barton R, Brooks R, MaloneLee J. Intravesical atropine compared to oral oxybutynin for neurogenic detrusor overactivity: a double-blind, randomized crossover trial. J Urol. 2007;177:208-13.

107. Staskin DR, Dmochowski RR, Sand PK, Macdiarmid SA, Caramelli KE, Thomas H, Hoel G. Efficacy and safety of oxybutyninchloride topical gel for overactive bladder: a randomised, double blind, placebocontrolled, multicentre study. J Urol. 2009;181:1764-72.

108. Sand PK, Davila GW, Lucente VR, Thomas H, Caramelli KE, Hoel G. Efficacy and safety of oxybutynin chloride topical gel for women with overactive bladder syndrome. Am J Obstet Gynecol. 2012;206:e1-6.

109. Cohn JA, Brown ET, Reynolds WS, Kaufman MR, Milam DF, Dmochowski RR. An update on the use of transdermal oxybutynin in the management of overactive bladder disorder. Ther Adv Urol. 2016;8:83-90.

110. Gleason JM, Daniels C, Williams K, Varghese A, Koyle MA, Bägli DJ, Pippi Salle JL, Lorenzo AJ. Single center experience with oxybutynin transdermal system (patch) for management of symptoms related to non-neuropathic overactive bladder in children: an attractive, well tolerated alternative form of administration. J Pediatr Urol. 2014;10:753-7.

111. Yamaguchi $O$, Chapple CR. $\beta 3$-adrenoceptorsinurinary bladder. Neurourol Urodyn. 2007;26:752-6.

112. Eltink C, Lee J, Schaddelee M, Zhang W, Kerbusch V, Meijer J, van Marle S, Grunenberg N, Kowalski D, Drogendijk T, Moy S, Iitsuka H, van Gelderen M, Matsushima H, Sawamoto T. Single dose pharmacokinetics and absolute bioavailability of mirabegron, a $\beta_{3}$-adrenoceptor agonist for treatment of overactive bladder. Int J Clin Pharmacol Ther. 2012;50:838-50.

113. Iitsuka $H$, van Gelderen $M$, Katashima $M$, Takusagawa S, Sawamoto T. Pharmacokinetics of mirabegron, a $\beta 3$-adrenoceptor agonist for treatment of overactive bladder, in healthy east asian subjects. Clin Ther. 2015;1(37):1031-44.

114. Herschorn S, Barkin J, Castro-Diaz D, Frankel JM, Espuna-Pons M, Gousse AE, Stölzel M, Martin N, Gunther A, Van Kerrebroeck P. A phase III, randomized, double-blind, parallelgroup, placebo-controlled, multicentre study to assess the efficacy and safety of theb3adrenoceptor agonist, mirabegron, in patients with symptoms of overactive bladder. J Urol. 2013;82:313-20.

115. Khullar V, Amarenco G, Angulo JC, Cambronero J, Høye K, Milsom I, Radziszewski P, Rechberger T, Boerrigter P, Drogendijk T, Wooning M, Chapple C. Efficacy and tolerability of mirabegron, a b3-adrenoceptor agonist, in patients with overactive bladder: results from a randomised Europeanen-Australian Phase 3 Trial. Eur Urol. 2013;63:283-95.

116. Chapple CR, Kaplan SA, Mitcheson D, Klecka J, Cummings J, Drogendijk T, Dorrepaal C, Martin N. Randomized doubleblind, active-controlled phase 3 study to assess 12-month safety and efficacy of mirabegron, a $\beta(3)$-adrenoceptor agonist, in overactive bladder. Eur Urol. 2013;64:296-305.

117. Nitti VW, Auerbach S, Martin N, Calhoun A, Lee M, Herschorn S. Results of a randomised Phase III trial of mirabegron in patients with overactive bladder. J Urol. 2013;189:1388-95.

118. Martan A, Masata J, Krhut J, Zachoval R, Hanus T, Svabik K. Persistence in the treatment of overactive bladder syndrome 
$(\mathrm{OAB})$ with mirabegron in a multicenter clinical study. Eur $\mathrm{J}$ Obstet Gynecol Reprod Biol. 2016;23(210):247-50.

119. Ohlstein EH, von Keitz A, Michel MC. A multicentre, double blind, randomised, placebo controlled, trial of the 3adrenoceptor agonist solabegron for overactive bladder. Eur Urol. 2012;62:834-40.

120. Blais AS, Nadeau G, Moore K, Genois L, Bolduc S. Prospective pilot study of mirabegron in pediatric patients with overactive bladder. Eur Urol. 2016;70:9-13.

121. Morin F, Blais AS, Nadeau G, Moore K, Genois L, Bolduc S. Dual therapy for refractory overactive bladder in children: a prospective open-label study. J Urol. 2016;197(4):1158-63

122. Bolduc S, Moore K, Lebel S, Lamontagne P, Hamel M. Double anticholinergic therapy for refractory overactive bladder. J Urol. 2009;182:2033-8.

123. Nadeau G, Schröder A, Moore K, Genois L, Lamontagne P, Hamel M, Pellerin E, Bolduc S. Double anticholinergic therapy for refractory neurogenic and nonneurogenic detrusor overactivity in children: long-term results of a prospective open-label study. Can Urol Assoc J. 2014;8:175-80.

124. Fahmy A, Youssif M, Rhashad H, Mokhless I, Mahfouz W. Combined low-dose antimuscarinics for refractory detrusor overactivity in children. J Pediatr Urol. 2016;12:219.e1-5.

125. Nardulli R, Losavio E, Ranieri M, Fiore P, Megna G, Bellomo RG, Cristella G, Megna M. Combined antimuscarinics for treatment of neurogenic overactive bladder. Int J Immunopathol Pharmacol. 2012;25:35S-41S.

126. Hsieh PF, Chiu HC, Chen KC, Chang CH, Chou EC. Botulinum toxin A for the treatment of overactive bladder. Toxins. 2016;8(3):59. doi:10.3390/toxins8030059.

127. Hassouna T, Gleason JM, Lorenzo AJ. Botulinum toxin A's expending role in the management of pediatric lower urinary tract dysfunction. Curr Urol Rep. 2014;15:426-32.

128. Schulte-Baukloh H, Michael T, Stürzebecher B, Knispel HH. Botulinum-a toxin detrusor injection as a novel approach in the treatment of bladder spasticity in children with neurogenic bladder. Eur Urol. 2003;44:139-43.

129. Altaweel W, Jednack R, Bilodeau C, Corcos J. Repeated intradetrusor botulinum toxin type $\mathrm{A}$ in children with neurogenic bladder due to myelomeningocele. $\mathrm{J}$ Urol. 2006;175:1102-5.

130. Kroll P, Jankowski A, Zachwieja J, Zaniew M, Mańkowski P, Harasymczuk J, Antczak A, Murias M. Endoscopic augmentation of neurogenic bladder with botulinum-A toxin in children. Pol Merkur Lekarski. 2008;24:15-7.

131. Kroll P, Jankowski A, Sołtysiak J, Murias M, Skrzypczak M, Zachwieja J. Botulinum toxin-A injections in children with neurogenic bladder. Nephro-Urol Mon. 2011;2:125-8.

132. Sager C, Burek C, Bortagaray J, Corbetta JP, Weller S, Durán V, Lopez JC. Repeated injections of intradetrusor onabotulinumtoxinA as adjunctive treatment of children with neurogenic bladder. Pediatr Surg Int. 2014;30:79-85.

133. Sahai A, Dowson C, Khan MS, Dasgupta P, GKT Botulinum Study Group. Repeated injections of botulinum toxin-A for idiopathic detrusor overactivity. Urology. 2010;7:552-8.

134. Nørdling J. Relationship of the sympathetic nervous system to lower motor neurone lesions and the bladder. Clin Sci. 1986;70:51s-5s.

135. Khanna OP. Disorders of micturition. Neuropharmacologic basis and results of drug therapy. Urology. 1976;8:316-28.

136. Krane RJ, Olsson CA. Phenoxybenzamine in neurogenic bladder dysfunction. I. A theory of micturition. J Urol. 1973;110:650-2.

137. Stockamp K. Treatment with phenoxybenzamine of upper urinary tract complications caused by infravesical obstruction. J Urol. 1975;113:128-31.
138. Yamanishi T, Yasuda K, Sakakibara R, Hattori T, Tojo M. The effectiveness of terazosin, an alpha1-blocker, on bladder neck obstruction as assessed by urodynamic hydraulic energy. BJU Int. 2000;85:249-53.

139. Hansen BJ, Nordling J, Mensink HJ, Walter S, Meyhoff HH. Alfuzosin in the treatment of benign prostatic hyperplasia: Effects on symptom scores, urinary flow rates and residual volume. A multicentre, double-blind, placebo-controlled trial. ALFECH Study Group. Scand. J Urol Nephrol Suppl. 1994;157:169-76.

140. Shim SR, Kim JH, Choi H, Lee WJ, Kim HJ, Bae MY, Hwang $\mathrm{SD}$, Kim KH, Bae JH, Yoon SJ. General effect of low-dose tamsulosin $(0.2 \mathrm{mg})$ as a first-line treatment for lower urinary tract symptoms associated with benign prostatic hyperplasia: a systematic review and meta-analysis. Curr Med Res Opin. 2015;31:353-65.

141. de Voogt HJ, van der Sluis C. Preliminary evaluation of alphaadrenergic blocking agents in children with neurogenic bladder due to myelomeningocele. Dev Med Child Neurol Suppl. 1976;37:82-8.

142. Schulte-Baukloh H, Michael T, Miller K, Knispel HH. Alfuzosin in the treatment of high leak-point pressure in children with neurogenic bladder. BJU Int. 2002;90:716-20.

143. Abrams P, Amarenco G, Bakke A, Buczyński A, Castro-Diaz D, Harrison S, Kramer G, Marsik R, Prajsner A, Stöhrer M, et al. Tamsulosin: efficacy and safety in patients with neurogenic lower urinary tract dysfunction due to suprasacral spinal cord injury. J Urol. 2003;170:1242-51.

144. Kakizaki H, Ameda K, Kobayashi S, Tanaka H, Shibata T, Koyanagi T. Urodynamic effects of alpha1-blocker tamsulosin on voiding dysfunction in patients with neurogenic bladder. Int $\mathrm{J}$ Urol. 2003;10:576-81.

145. Cain MP, Wu SD, Austin PF, Herndon CD, Rink RC. Alpha blocker therapy for children with dysfunctional voiding and urinary retention. J Urol. 2003;170:1516-7.

146. Yucel S, Akkaya E, Guntekin E, Kukul E, Akman S, Melikoglu M, Baykara M. Can alpha-blocker therapy be an alternative to biofeedback for dysfunctional voiding and urinary retention? A prospective study. J Urol. 2005;174:1612-5.

147. Kramer SA, Rathbun SR, Elkins D, Karnes RJ, Husmann DA. Double-blind placebo controlled study of alpha-adrenergic receptor antagonists (doxazosin) for treatment of voiding dysfunction in the pediatric population. J Urol. 2005;173:2121-4.

148. Kroll P, Jażdżewska A, Maćkowiak J. A comparative study of selective $\alpha$ 1-blockers (doxazosin) and behavioural therapy for treating discoordinated voiding in children. BJU Int. 2004;93(Suppl 2):66.

149. Gołębiewski A. Selective $\alpha$-blockers for treating dysfunctional voiding in children. BJU Int. 2004;93(Suppl 2):67.

150. Abraham MK, Nasir AR, Sudarsanan B, Puzhankara R, Kedari PM, Unnithan GR, Damisetti KR, Narayanan T. Role of alpha adrenergic blocker in the management of posterior urethral valves. Pediatr Surg Int. 2009;25:1113-5.

151. VanderBrink BA, Gitlin J, Toro S, Palmer LS. Effect of tamsulosin on systemic blood pressure and nonneurogenic dysfunctional voiding in children. J Urol. 2009;181:817-22.

152. Van Batavia JP, Combs AJ, Horowitz M, Glassberg KI. Primary bladder neck dysfunction in children and adolescents III: results of long-term alpha-blocker therapy. J Urol. 2010;183:724-30.

153. Homsy Y, Arnold P, Zhang W. Phase IIb/III dose ranging study of tamsulosin as treatment for children with neuropathic bladder. J Urol. 2011;186:2033-9.

154. Kroll P, Gajewska E, Zachwieja J, Sobieska M, Makoski P. An evaluation of the efficacy of selective alpha-blockers in the treatment of children with neurogenic bladder dysfunction- 
preliminary findings. Int J Environ Res Public Health. 2016;15, 13(3). pii: E321.

155. Kroll P, Jankowski A, Maćkowiak J. The comparative study on selective alpha1-blocker and behavioural therapy in the treatment of discoordinated voiding in children. Przegl Lek. 2006;63(Suppl 3):226-8.

156. Yang SS, Wang CC, Chen YT. Effectiveness of alpha1-adrenergic blockers in boys with low urinary flow rate and urinary incontinence. J Formos Med Assoc. 2003;102(8):551-5.

157. Austin PF, Homsy YL, Masel JL, Cain MP, Casale AJ, Rink RC. Alpha-adrenergic blockade In children with neuropathic and nonneuropathic voiding dysfunction. J Urol. 1999;162:1064-7.
158. Erturhan S, Bayrak O, Sarica K, Seckiner I, Baturu M, Sen H. Efficacy of medical expulsive treatment with doxazosin in pediatric patients. Urology. 2013;81:640-3.

159. Bogaert G, Beckers G, Lombaerts R. The use and rationale of selective alpha blockade in children with non-neurogenic neurogenic bladder dysfunction. Int Braz J Urol. 2004;30:128-34.

160. https://clinicaltrials.gov/ct2/search/index. Accessed March 2017. 